\title{
Dieng Culture Festival and its Culture Conservation Dilemma
}

\author{
Agung Setiawan \\ Magister Management of Tourism \\ STIEPARI \\ Semarang, Indonesia \\ agdistwn@gmail.com
}

\begin{abstract}
The purpose of this paper is to evaluate community-based tourism activities, the Dieng Culture Festival (DCF). The methods used is descriptive qualitative in case study and utilize the concept of cultural and tourism event for analysis. The results will be used as improvement for tourism activities planning in general. The DCF is an event designed for Dieng local society for "Ngruwat Gimbal" ceremony, a Central Javanese tradition that exists in the Dieng Kulon village of Batur, Banjarnegara. It has brought many visitors and multiplied local economic growth as well as community based tourism activities. Beside its success, DCF also has problems. Among of the problems are: 1) "Ngruwat Gimbal's ceremony as the main program on DCF event, by cutting the dreadlock from the Dieng Kulon kid's hair, has excluded the locals from participating in the ceremony, and served mostly for outsider, the non-local and foreign tourists. 2) The insertion of the "jazz diatas awan" in a local culture festival by some people, is considered not appropriate.The discussions result suggested that the DCF event needs to be more environmentally friendly, consider more on the preservation of the local culture, and involve all local people to participate in the event.
\end{abstract}

Keywords-Culture preservation, culture festival, communitybased tourism.

\section{INTRODUCTION}

Dieng Culture Festival (DCF) is a community cultural festival which was originally called as "Dieng cultural event", held to promote Javanese tradition in doing ruwatan for Dieng's children, when the kid's dreadlock hair is cut. Ruwatan is a purification ceremony that has become customary in Java. According to Poerwadarminta (1939) Ruwatan originated form ruwat word that means 1) uncontrolled danger 2) Request God's help to avoid the uncontrolled danger. The ruwatan is done in order to avoid the danger, bad luck free from curse and evil's influence, thus people can live in peace and safe. (p.534).

The uniqueness of ruwatan for children with the dreadlock hair, is that the phenomenon only exists in Dieng. Realizing the potential value of this tradition, a local community that has consciousness in tourism called as "Pokdarwis Dieng Pandawa" has set an idea to change the form of this ceremony into Dieng Culture Festival. Its concept is combining the culture with nature tourism and their mission is to empower Dieng economic. To establish their mission, Pokdarwis Dieng Pandawa active in the introduction to the public about the importance of tourism in various angles, one of them, in terms of economy, is to make economically independent society. In addition to DCF, Pokdarwis Dieng Pandawa also manage Dieng Kulon tourist villages, to provide all facilities and amenities such as Homestay, Handicrafts, Tour Guide, Agro Tourism, Art and Culture in the area of Dieng, and so on, that supporting the festival and provide the need of the tourist. Brohman J (1996) stated Community-based tourism development would seek to strengthen institutions designed to enhance local participation and promote the economic, social and cultural well-being of the popular majority. It would also seek to strike a balanced and harmonious approach to development that would stress considerations such as the compatibility of various forms of development with other components of the local economy; the quality of development, both culturally and environmentally; and the divergent needs, interests and potentials of the community and its inhabitants. (p.60).

During its fourth period, DCF has successfully attracted both domestic and foreign tourist. Dieng Culture Festival proved has helped raise the level of the people's economy through tourism. DCF not only aims to introduce the potential of tourism and arts and culture to the wider community as a tourist destination, but also to improve the economy of society. It turned out that tourism appeared as a pillar in addition to the agriculture sector.

Other related previous observation by Singgih Adi Nugroho (2014) is "Ngruwat Gimbal ceremony at East Dieng, Batur sub district, Banjar Negara regency" His observation is describing about the history, procession of the ceremony and the function of "Ngruwat Gimbal" where its conclusion was, up to now Dieng Society is still belief and doing the "ngruwat gimbal" ceremony as their tradition, to request for the safety and as expression of their gratitude to the God.

The difference between the above observations and what is written here is the angle in viewing the matter, this writing is more focus on the involvement of the local society on the festival as a means to conserve the local culture, and how the management selecting the entertainment as part of tourist attraction within Dieng Culture Festival.

Culture and tourism can indeed produce a profit, but should still cling to the meaning and sacredness. The tradition can be continued if the citizens with their local wisdom to believe the 
meaning of that tradition. Welfare society and local wisdom should be a major consideration when all parties will establish tourism policy. The culture can exist because people, originated from the community, and utilized for the public.

DCF as cultural events of Dieng Kulon's local tradition, should also involve all local residents to participate in the ceremony, so it will create a sense of pride and a sense of the culture belonging, but in reality during the implementation of the event, there are many locals that just become the spectators, who are standing outside the limiter lane that was set by the committee in the ruwatan ceremony area,

To provide more attraction on the implementation of the festival, DCF provides music jazz performance, named as jazzatasawan, where now it become its main agenda, Jazz music actually does not come from the local culture. Its election is aimed to attract more tourists visiting the DCF, but because jazz music is not a local cultural art, then both of the musicians and artists are not coming from the local people. This attraction is made as if just to accommodate the desires of tourists, since local people do not like jazz music. Apart from all of it, the local cultural arts should be considered to be made as a featured attraction in the DCF and not just be a complement to the show.

The purpose of writing this paper is to study the development trend and the impact of tourism activities on cultural change society. The benefit is to provide inputs for the planning of tourism and the management program of cultural events to the preservation of local traditions and its uniqueness.

\section{LITERATURE REVIEW}

According to Koentjoroningrat (1993,p.46). "Javanese people belief that there is a strongest power beyond other power that has been acknowledge such as magic, spirit or ancestor's spirit, ghost, devil, genie and other form that occupied their nearby life".

Based on their belief, Javanese people do the rite, called as ruwatan. Winnick (1997) said that, Rite means "a set or series of acts, usually involving religion or magic, with the sequence established by tradition". (p. 461). This ceremony is done with the intention to avoid the evil's influence such as bad luck, or disaster.

Ngruwat gimbal tradition is considered as people's cultural heritage that has been passed on from one generation to another. UNESCO (n.d. para.1) mentioned that Cultural heritage is not limited to material manifestations, such as monuments and objects that have been preserved over time . This notion also encompasses living expressions and traditions that countless groups and communities worldwide have inherited from their ancestors and transmit to their descendants, in most cases orally.

In order to maintain its uniqueness, it is important to preserve cultural heritage Sekler (2001) stated. There are many ways in which a cultural identity is formed and maintained. Much of the process has to do with intangible cultural heritage of a body of traditions and usages, rites, poetry, song, and dance. A great deal of all these are passed on orally through generations. Consequently, its survival is always threatened.

World Bank (2001) has warned that: "Cultural matrixes contain elements of the human collective memory - language, beliefs and transmitted from generation to generation. Cultural references and signs are essential to the formation of national, group, and individual identities."

Thus to be able to pass this tradition to the next generation, the participation of the local people who own the culture is extremely important.

TABLE I. COMPARISON BETWEEN THE TRADITIONAL AND MODERN EVENT IN DCF

\begin{tabular}{llllll}
\hline $\begin{array}{l}\text { Cultural } \\
\text { Events }\end{array}$ & $\begin{array}{l}\text { Cultural } \\
\text { Source }\end{array}$ & $\begin{array}{l}\text { Form of } \\
\text { Culture }\end{array}$ & $\begin{array}{l}\text { Form of } \\
\text { activities }\end{array}$ & Segments & Impact \\
\hline $\begin{array}{l}\text { Ritual } \\
\text { rambut } \\
\text { gimbal }\end{array}$ & Local & Traditional & Ritual & All ages & $\begin{array}{l}\text { Culture } \\
\text { existence }\end{array}$ \\
\hline $\begin{array}{l}\text { Jazz } \\
\text { atas } \\
\text { awan }\end{array}$ & Outside & Modern & $\begin{array}{l}\text { Entertai } \\
\text { nment }\end{array}$ & $\begin{array}{l}\text { Mostly } \\
\text { youngster }\end{array}$ & $\begin{array}{l}\text { Culture } \\
\text { change }\end{array}$ \\
\hline
\end{tabular}

\section{RESEARCH METHODS}

Qualitative method with descriptive analysis in a case study is dedicated to describe DCF as a means of Dieng Kulon culture conservation and local people involvement in the procession of "ruwatan rambut gimbal" ceremony. The study also analysis the loading of foreign cultures, such as jazz music to be the additional attractions within an implementation of a local cultural festival.

Data in qualitative research are derived from observation, interviews and documentation. Informants were selected from those that provide accurate data, namely: Tourism dept. of Banjarnegara regency, village staff, chairman Pokdarwis Dieng Pandawa as DCF management committee, and the villagers of Dieng Kulon. Description of the data obtained is used to explain the problem of research in this dilemma implementation and utilization of local traditions festival for tourism event. The results in understanding over the problems on the field and will be taken into consideration and suggestions for the implementation of similar activities in the future. Here is a table that contains an overview DCF event featured cultural characteristics of the source, its activities, and the segment who enjoy it, as well as the impact that may be caused.

\section{RESULTS AND DISCUSSION}

The idea of making DCF originated from the tradition of the Dieng Kulon people to do ngruwat gimbal ceremony on their child who has dreadlocks, which is then a set of people who have awareness of high tourism began to realize that the uniqueness of their culture has commercial value, thus they begin to have an idea to do the "ruwatan rambut gimbal" in bulk, This idea is actually good as this will be able to be made as a tourist attraction that is worth selling. However at the implementation of the ceremony, the committee does not 
involve all the local people to participate, due to the efficiency of the management and to give more space to the visitors to involve in the ceremony and give them a new unique experience. Thus there are lots of local people that only act as spectators at the outside lane of the procession area.

In order to make DCF has more value, then the committee made some kind of attractions and activities that are divided into (1) Natural Attractions, (2) Cultural Attractions, and (3) Things to Do Artificial. Those are consist of Jazz Atas Awan musical performance Dieng Film Festival, the Lantern Festival, Drinking Purwaceng Together, DCF Camping, Gimbal Hair dancing performance, Healthy Walk and Reforestation, as well as exhibitions.

Among these attractions, one concern is the performance of Jazz Atas Awan which the management committee set this up as an agenda that will always be installed in any implementation of DCF, although based on the results of field research it turns out there are opinions that the pros and cons of local residents and officials to the insertion of culture this outdoor event into DCF.

\section{A. Dreadlocks Hair Ritual Events}

\section{1) Kirab Budaya Cultural carnival}

A marching of the people to the site of the shaving ritual procession. Started from the house of the indigenous Stakeholder and stopped near the Spring Zone Maerokoco or Spring Sedayu to get around the village escorted by the elders, community leaders, the group of traditional arts community and the public.The marching procession consisted of two main elder's figures bodyguard, named as ing ngayodya, two men carrying incense (furnace repellent reinforcements) and the soldiers carrying traditional weapon such as spears, keris and other heirlooms, continued by the two cucuk lampah's flower carrier. Next to it is the line that carrying the dreadlock child requests (offerings and ubo rampe) they carry Buju Abang, Buju White, Buju Ireng, Buju Yellow, Buju Robyang, Buju Kleung, Buju Sanggabuwana, Buju Tulak, Buju Bake, Buju Kupat, Rakan Jajan market, Rakan fruit , Banana King Gold, Kinang, Makeup Tool and a variety of cups with 14 kinds of drinks and Bobo Ronyong. The children who want to be ruwated rides the andong or traditional transportation which followed by the traditional art troupe that will present performances until the end of shearing ritual procession.

At the time of carnival, the organizers gives an opportunity for 80 visitors who interested to participate in carnival culture by wearing traditional clothes.

\section{2) Jamasan (Cleansing)}

Jamasan (bathing) dreadlock hair child that held in Spring Sedayu or Spring Maerokoco precisely in the north Darmasala Arjuna temple complex. To enter the Spring Sedayu, the child beggars are shaded under a long shroud called as Robyong umbrellas to walk around the spring Maerokoco while accompanied by music Gongso.

\section{3) Pencukuran (Shearing)}

The procession carried out by the community leaders who accompanied and guided directly by the elder. The tourists who already have tickets are allowed to enter the Arjuna temple complex, to witness the ceremony in person, while for tourists and locals who do not have tickets are only allowed to see this ritual outside the fence that have been made by committee. After shaving the dreadlock hair completed, followed by thanksgiving and prayer. Then all ubo potpourris are given to all visitors as is believed to bring blessings to those who took it

\section{4) Ngalap Berkah (Expecting the blessing)}

It is trusted by the local community can bring blessings to those who follow it, In this occasion people compete to get the rice cone from the offering and eat it for salvation. This ceremony is conducted by traditional authority's leaders and local community leaders. During that time, visitors can also witness the presentation artistic attractions.

\section{5) Pelarungan ( Floating )}

After shearing is complete then the procession closed with pelarungan, where the cutting of dreadlock hair is floated out into Balekambang lake.

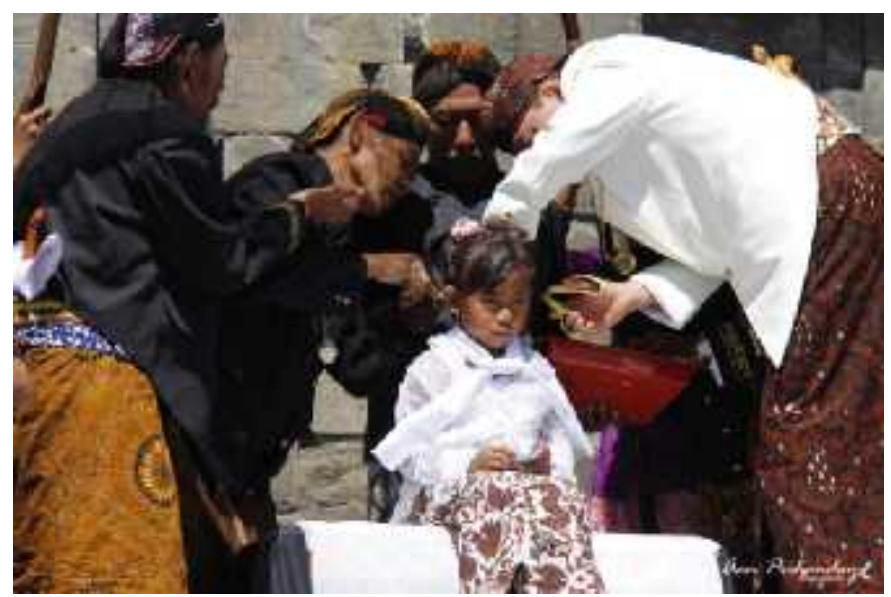

Fig. 1. Shearing procession

\section{B. Jazz atas awan}

Jazz on the cloud performance in the event of DCF is an idea that comes from the event management committee, with the aim to deliver attractions that can provide value-sale that attracted more tourists to come to the event DCF. Jazz Atas Awan performance made on an open stage with Arjuna temple as the background, with interesting lighting system and sound system made support for supporting an outdoor event so that the sound of music can make the audience swayed with the dynamic of jazz rhythms. According the committee, the show this year lasted for two days. The reason, many musicians who are interested to play in these performances.

The success of jazz atas awan performances has started since the implementation of the fourth DCF, now established as a regular agenda by a management committee. Despite the fact that the local population itself, is not involved in jazz atas awan performances and most of them are not so fond of jazz performances

From interviews were obtained either from organizers and locals alike, it produced two different camps, where the author 
will mark it with a positive statement of opinion approving the programs implemented by the management committee for the DCF and negative for those who gave disapprove opinions.

TABLE II. EVENT RUwATAN RAMBUt Gimbal

\begin{tabular}{|c|c|c|c|c|}
\hline Factors & Group 1 & Reason & Group 2 & Reason \\
\hline $\begin{array}{l}\text { Ritual made as } \\
\text { the attraction }\end{array}$ & Agree & $\begin{array}{l}\text { Income and } \\
\text { culture } \\
\text { conservation }\end{array}$ & Agree & $\begin{array}{l}\text { Income \& } \\
\text { culture } \\
\text { conservation }\end{array}$ \\
\hline $\begin{array}{l}\text { Only visitors } \\
\text { with full ticket } \\
\text { allowed to } \\
\text { enter } \\
\text { procession area }\end{array}$ & Agree & $\begin{array}{l}\text { Limited } \\
\text { space and } \\
\text { visitor } \\
\text { convenience }\end{array}$ & Disagree & $\begin{array}{l}\text { Visitors not } \\
\text { involve in } \\
\text { the } \\
\text { ceremony }\end{array}$ \\
\hline $\begin{array}{l}\text { Involvement all } \\
\text { local society in } \\
\text { the ceremony }\end{array}$ & No need & Complicated & Needed & $\begin{array}{l}\text { Proudness } \\
\& \\
\text { ownership }\end{array}$ \\
\hline $\begin{array}{l}\text { Involvement of } \\
\text { the visitors in } \\
\text { the ceremony }\end{array}$ & $\begin{array}{l}\text { Needed } \\
\text { with } \\
\text { limitation }\end{array}$ & $\begin{array}{l}\text { Give } \\
\text { experience }\end{array}$ & No need & $\begin{array}{l}\text { Not part of } \\
\text { their culture }\end{array}$ \\
\hline
\end{tabular}

Group 1 commented that the involvement of all local people in shearing dreadlock hair kid rituals is limited with the reason to simplify the management and give more space to the visitors to be able to participate at the event that will offer new experience for them, such as the opportunity to follow the marching of the dreadlock hair kid by wearing the traditional costume. Regarding the election of jazz atas awan as one of the main DCF program due to its success to make DCF event more popular. They said if the number of visitors coming for jazz atas awan performance almost close to those who wants to see the ruwatan rambut gimbal itself. They very curious on the jargon "jazz atas awan" which means jazz on the cloud where visitors imagination is brought to. They also said that jazz atas awan performance make the visitors stay longer and spend more as the jazz atas awan performance is held for two nights. (POSITIVE).

Group 2 commented the insertion of other culture such jazz atas awan is only dedicated to the visitor while the local people itself doesn't like such kind of music also none of the local artist involvement in this performance. They also worry that the vibration produced by the sound system will destruct the structure of the Candi Arjuna, as they said that the constructions of the Dieng plateau land is instable thus the vibration may eventually cause the damage to the candi construction. They also said that the committee must have the strategy to dig and explore more about the local culture and become more innovative in creating the local arts culture to become a major attraction that has higher value, their idea is performing theater that involving the local artist to tell the rich folk story of the Dieng mountain. (NEGATIVE )

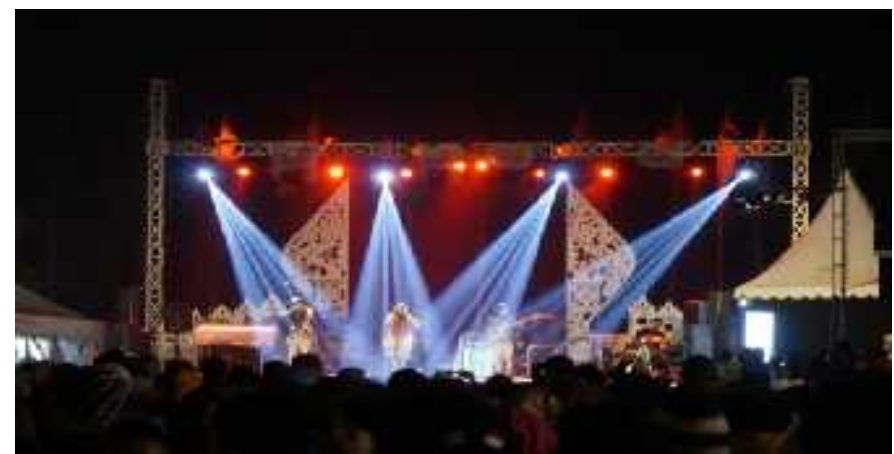

Fig. 2. Jazz atas awan performance

TABLE III. EVENT JAZZ ATAS AWAN

\begin{tabular}{|c|c|c|c|c|}
\hline Factors & Group 1 & Reason & Group 2 & Reason \\
\hline $\begin{array}{l}\text { Suitable with } \\
\text { DCF event }\end{array}$ & Agree & $\begin{array}{l}\text { Attract more } \\
\text { visitors and } \\
\text { income }\end{array}$ & Disagree & $\begin{array}{l}\text { Outside } \\
\text { culture }\end{array}$ \\
\hline $\begin{array}{l}\text { Comment on the } \\
\text { show }\end{array}$ & Good & $\begin{array}{l}\text { Following } \\
\text { later trend }\end{array}$ & $\begin{array}{l}\text { Not } \\
\text { good }\end{array}$ & $\begin{array}{l}\text { Prefer local } \\
\text { music }\end{array}$ \\
\hline $\begin{array}{l}\text { Possibility to be } \\
\text { replaced with } \\
\text { local show }\end{array}$ & Disagree & $\begin{array}{l}\text { Good show } \\
\text { for visitors, } \\
\text { bring prestige } \\
\text { to the area } \\
\text { and generate } \\
\text { more income }\end{array}$ & Agree & $\begin{array}{l}\text { Replace with } \\
\text { more } \\
\text { attractive local } \\
\text { culture show. }\end{array}$ \\
\hline $\begin{array}{l}\text { Bad impact on } \\
\text { land and candi } \\
\text { construction }\end{array}$ & Disagree & $\begin{array}{l}\text { Land around } \\
\text { Candi is } \\
\text { stable }\end{array}$ & Agree & $\begin{array}{l}\text { Believed to be } \\
\text { the cause of } \\
\text { disposition on } \\
\text { one of the } \\
\text { candi. }\end{array}$ \\
\hline
\end{tabular}

The data analysis of the results of interviews with informants, especially related to the problem of exploitation of ritual as an attraction, selling tickets to watch the procession, and the tradition of community involvement owner / local. The results of the interview and their opinions can be tabulated as follows: The data analysis of the results of interviews with informants, especially related to the problem of exploitation of ritual as an attraction, selling tickets to watch the procession, and the tradition of community involvement owner / local. The results of the interview and their opinions can be tabulated as follows.

Dilemma already emerged of dissent informant group, where the $1^{\text {st }}$ group is representing a majority of the committee, and the second group represents the majority of society, both groups have fairly logical reasons despite contradictory.

Then related to jazzatasawan event, the opinion of the informants group is tabulated below. In this table, the opinions also contradict between the two groups, but regarding the truths of the festival influences on the land stability, especially around the temple area needs to be based on the technical knowledge of construction and from the grouping of public opinion about the implementation of the DCF then it can be concluded that there was a problem quite serious, especially with the two parties who have different opinions, related to community involvement in ritual cutting dreadlocks and application of jazz music as an attraction in the Dieng Culture festival, as well as the impact thereof. 
There is a group of communities expressed their concern about the impact that can be caused by the non-involvement of the local people. However just letting the locals to become spectators that standing outside delimiter arena procession, it will be possible that sooner or later this will reduce the concern of local communities to this tradition, and could ultimately threaten the sustainability of the tradition itself. While segments of society that agree with the non-involvement of the local population, further stressing the reasons management efficiency and effectiveness, as well as to provide space for tourists in order to participate in the event and provide new experience for the tourists.

The application of jazz music in the DCF for community groups who refuse because they prefer the local cultural arts and worry about the effect of vibration caused by the sound system, as it can damage the soil in the highlands Dieng construction that is unstable. Meanwhile segments of society who agree with their performances of jazz music is because the number of tourists lover of jazz music is big enough, even nearly comparable to the number of tourists who want to see "ruwatan" of the child with dreadlocks hair. The addition of the event, and length of its performance duration which held for two nights, will automatically increase the tourist spending. The table shows that the opinion between the two groups are different, but the truth about the impact of the festival activity toward the candi and its surrounded, need to based by the knowledge on the technical construction.

\section{CONCLUSION}

In certain circumstances, the involvement of the local society in the procession of "ruwatan rambut gimbal" ceremony may require, as this will raise the feeling of proudness and ownership that eventually, this tradition can be passed from generation to generation.

Adoption of foreign culture such as jazz music, is indeed the case that were not appropriate when viewed through the lens of local cultural festival concept. But when culture is used as a tourist attraction then the effect is the culture will change. Cultural actors will create new exciting event that might even be able to accommodate the needs and desires of tourists. But in accommodating the needs and desires of tourists then factors such as the capacity of objects and tourist arrangements must be considered.

\section{REFERENCES}

Brohman, J, (1996). New Directions in Tourism for the Third World, Annals of Tourism Research, 23(1):48-70:60

Koentjaraningrat, 1984. Kebudayaan Jawa. Jakarta: PN Balai Pustaka.

Sekler, E. (2001). Sacred spaces and the search for authenticity in the Kathmandu Valley. In Serageldu, I., Shluger, E., \& Martin-Brown, J. (Eds). Historic cities and sacred sites: Cultural roots for urban futures. Washington DC: The World Bank.

Singgih, Adi Nugroho (2014) Upacara Ngruwat Gimbal di Desa Dieng Kulon Kecamatan Batur Kabupaten Banjarnegara. Retrieved from http://eprints.uny.ac.id/19977/1/Singgih\%20Adi\%20Nu groho\%2007205244027.pdf

Unesco Intangible Cultural Heritage (n.d.)

http://www.unesco.org/culture/ich/en/what-isintangible-heritage-00003

Winnick. (1977). Islam in Java: Normative Piety and Myticism. Tucson: University of Arizona Press.

World Bank (2001) Historic Cities and Scared sites: Cultural Roots for Urban Futures. Washington DC: World Bank. 